\title{
Kemampuan Guru dalam Mengelola Kelas selama Pembelajaran Covid-19 pada Anak Usia Dini
}

\author{
Yolanda Pahrul ${ }^{1}$, Joni' ${ }^{1}$, Leli Marlina ${ }^{1}$ \\ Pendidikan Guru Pendidikan Anak Usia Dini, Universitas Pahlawan Tuanku Tambusai, \\ Indonesia ${ }^{(1)}$ \\ DOI: 10.31004/obsesi.v6i3.1807
}

\begin{abstract}
Abstrak
Kemampuan mangelola kelas adalah keterampilan guru untuk menciptakan dan memelihara kondisi belajar yang optimal dan mengembalikannya bila terjadi gangguan dalam proses belajar mengajar. Tujuan penelitian untuk mengetahui kemampuan guru dalam mengelola kelas selama pembelajaran masa pandemi Covid-19 di TK Bunga Teratai Kec. Tapung Kab. Kampar. Jenis penelitian adalah kualitatif dengan teknik pengumpulan data berupa wawancara dan observasi. Informan adalah 3 orang guru. Teknik analisis data menggunakan data reduction, data display, conclusion drawing/verification. Hasil penelitian menunjukkan bahwa guru-guru TK Bunga Teratai telah memimiliki kemampuan mengelola kelas hal ini terlihat dari pengaturan yang berhubungan dengan tingkah laku, kedisiplinan, perhatian, minat belajar, dan dinamika kelompok. Rekomendasi yang dapat disampaikan adalah selama pembelajaran masa pandemi Covid-19 pihak sekolah hendaknya mempersiapkan fasilitas selama covid-19 ini, seperti kecukupan cairan disinfektan, sabun cuci tangan, air bersih di setiap fasilitas, dan hand sanitizer.
\end{abstract}

Kata Kunci: kemampuan guru; mengelola kelas; covid-19

\begin{abstract}
The ability to manage the classroom is the teacher's skill to create and maintain optimal learning conditions and restore them if there are disturbances in the teaching and learning process. The purpose of this study was to determine the teacher's ability to manage classes during the Covid-19 pandemic learning period at Bunga Teratai Kindergarten, Kec. Tapung Kab. Kampar. This type of qualitative research with data collection techniques in the form of interviews and observations. Informants are 3 teachers. The data analysis technique uses data reduction, data presentation, conclusion drawing/verification. The results showed that the teachers of the Bunga Teratai Kindergarten had the ability to manage this class as seen from the arrangements related to behavior, discipline, attention, interest in learning, and group dynamics. The recommendation that can be conveyed is that during the learning period of the Covid-19 pandemic, the school prepares facilities during this covid-19, such as liquid disinfectant, soap for hand washing facilities, clean water in each, and hand sanitizer.
\end{abstract}

Keywords: teacher ability; managing class; covid-19

Copyright (c) 2021 Yolanda Pahrul, et al.

$\triangle$ Corresponding author:

Email Address : yolandapahrul@gmail.com (Bangkinang, Indonesia)

Received 17 August 2021, Accepted 13 November 2021, Published 30 December 2021 


\section{PENDAHULUAN}

Pengelolaan kelas dibutuhkan keterampilan khusus, oleh karena di dalam kelas itu terdapat unsur material yaitu benda-benda seperti ruangan, perabot, alat pelajaran dan manusia (siswa) sebagai obyek sekaligus subyek pendidikan. Guru dapat mengelola kelas dengan baik dari aspek fisik tetapi, belum tentu mampu mengelola kelas yang menyangkut peserta didik. Rumitnya pengelolaan kelas dari aspek peserta didik karena berhubungan dengan sifat, karakter dan kondisi sosial peserta didik. Dari sudut pandang inilah sehingga pengelolaan kelas juga bermakna pembinaan (Kadir, 2014).

Pengelolaan kelas merupakan pola tingkah laku yang kompleks dan guru menggunakannya untuk menciptakan dan mempertahankan kondisi kelas sedemikian rupa sehingga anak didik dapat menciptakan tujuan pengajaran secara efisien dan memungkinkan siswa tetap fokus dalam belajar (Santiyadnya, 2017). Larrives dalam (Santiyadnya, 2017) menyatakan pengelolaan kelas adalah satu bagian kritis yang mencampurkan tiga cara strategi mengajar efektif yang meliputi isi materi penuh arti, strategi mengajar dan struktur organisasi untuk mendukung belajar produktif. Selain itu mengelola kelas adalah upaya yang dilakukan oleh guru untuk mengorganisir siswa dalam ruang, waktu dan bahan sedemikian rupa sehingga intruksi isi serta siswa dalam belajar bisa berlangsung. Jadi pengelolaan kelas yang efektif adalah syarat bagi pengajaran yang efektif dan berhasil.

Sedangkan tujuan pengelolaan kelas pada hakikatnya telah terkandung dalam tujuan pendidikan. Secara umum tujuan pengelolaan kelas adalah penyediaan fasilitas bagi bermacam-macam kegiatan belajar siswa dalam lingkungan sosial, emosional, dan intelektual dalam kelas. Selain itu, pengelolaan kelas bertujuan agar setiap anak di kelas dapat bekerja dengan tertib sehingga segera tercapai tujuan pengajaran secara efektif dan efisien (Adhyati, 2016).

Kemampuan guru dalam mengelola kelas adalah kemampuan guru untuk menciptakan dan memelihara kondisi belajar yang optimal dan mengembalikannya manakala terjadi hal-hal yang dapat mengganggu suasana pembelajaran dengan memanfaatkan sumber daya yang ada yang meliputi pengelolaan peserta didik dan fasilitas yang mengarah pada penyiapan bahan belajar, penyiapan sarana dan alat peraga, pengaturan ruang belajar, perwujudan situasi/kondisi proses belajar mengajar dan pengaturan waktu sehingga pembelajaran berjalan dengan baik dan tercapainya tujuan pembelajaran (Suwardi, 2019).

Berdasarkan penjelasan di atas, dapat disimpulkan bahwa yang memiliki kewenangan untuk mengelola kelas adalah guru, karena guru merupakan penanggung jawab kegiatan belajar mengajar, sehingga guru dituntut agar mampu mengelola kelas dengan baik dan efektif, apalagi mengelola kelas pada masa pandemi Covid-19 pada saat ini.

Pandemi COVID-19 (corona virus disease 2019) pertama muncul di akhir tahun 2019 tepatnya di Wuhan, China (Anugrahana, 2020). COVID-19 merupakan sebuah virus yang penularannya sangat cepat dan sulit untuk mengetahui ciri-ciri orang yang sudah terjangkit virus ini karena masa inkubasinya kurang lebih selama 14 hari. Hampir seluruh negara mengalami dampak pandemi ini, hingga banyak negara-negara yang menetapkan status lockdown dan antisipasi lainnya guna memutuskan mata rantai penyebaran COVID-19 (Hilna Putria, Luthfi Hamdani Maula, 2020).

Akibat kebijakan ini, banyak sektor yang lumpuh, misalnya sektor ekonomi terpenting lumpuh akibat pandemi ini. Selain sektor ekonomi yang terkena dampak, pendidikan juga menjadi salah satu sektor yang juga merasakan dampak langsung dari pandemi ini. Setidaknya 1,5 miliar anak usia sekolah di 188 negara terdampak COVID-19, termasuk 60 juta di Indonesia, menurut UNESCO. Sekolah diliburkan akibat pandemi ini, guna mencegah penyebaran COVID19 (Ayu Wulandari, 2020).

Demikian juga dengan Perserikatan Bangsa-Bangsa atau United Nations mengindikasikan bahwa salah satu sektor yang terkena dampak wabah ini adalah dunia pendidikan. Hal ini menyebabkan beberapa negara menutup sekolah dan universitas. Untuk mencegah penyebaran Covid 19, World Health Organization (WHO) merekomendasikan 
penghentian sementara aktivitas yang dapat menimbulkan keramaian (Oktafia Ika Handarini \& Siti Sri Wulandari, 2020).

Sehingga selama masa pandemic COVID-19 tersebut, seluruh negara termasuk Indonesia diharuskan melaksanakan pembelajaran dirumah atau online sebagai solusi melanjutkan sisa semester. Pembelajaran online didefinisikan sebagai pengalaman transfer pengetahuan menggunakan video, audio, gambar, komunikasi teks, perangkat lunak dan dengan dukungan jaringan internet (Herliandry, Nurhasanah, Suban, \& Kuswanto, 2020).

Seiring dengan berjalannya waktu, untuk semester genap tahun ajaran 2020/2021, Menteri Pendidikan Kebudayaan Nadiem Makarim mengatakan bahwa sekolah boleh melaksanakan pembelajaran tatap muka dengan memenuhi syarat tertentu, yaitu: 1) ada izin dari tiga pihak, yaitu pemda/kanwil/kantor kemenag, kepala sekolah, dan perwakilan orang tua, 2) sekolah menyediakan daftar periksa suhu siswa dan guru, dan 3) menerapkan protokol kesehatan yang ketat (Mendikbud, Panduan penyelenggaraan pembelajaran pada tahun ajaran 2020/2021 di masa pandemi Covid-19, 2021)

Melihat panduan penyelenggaraan pembelajaran yang dikeluarkan oleh Mendikbud di atas, maka TK Bunga Teratai Kecamatan Tapung Kabupaten Kampar untuk semester 2 ini melaksanakan pembelajaran tatap muka dengan tetap menjaga protokol kesehatan yang ketat. Dengan demikian, proses pembelajaran selama pandemi Covid-19 ini guru harus mampu mengelola kelas dengan baik dan efektif, agar anak benar-benar dapat menyerap dan menerima materi yang disampaikan guru.

Namun, berdasarkan observasi awal yang penulis lakukan di TK Bunga Teratai Kecamatan Tapung Kabupaten Kampar pada tanggal 02 juni 2021 diketahui bahwa selama pandemi Covid-19 pengelolaan kelas belum memenuhi standar prokes pembelajaran, seperti: 1) jarak tempat duduk anak masih terlalu dekat, apalagi ketika duduk bersama kelompok, 2) siswa dibiarkan tampil kedepan lebih dari 3 orang, 3) kurang disiplinnya anak untuk mencuci tangan, anak mencuci tangan ketika masuk kelas saja, dan 4) guru tidak menegur siswa yang sering bermain dan berjalan.

\section{METODOLOGI}

Jenis penelitian yang digunakan adalah penelitian kualitatif dengan tujuan untuk mendapatkan gambaran kemampuan guru dalam mengelola kelas selama pembelajaran masa pandemi Covid -19 di TK Bunga Teratai Kec. Tapung Kab. Kampar pada bulan april hingga juni dengan teknik pengumpulan data wawancara dan observasi, dengan sumber data utama adalah guru-guru TK Bunga Teratai yang berjumlah 3 orang guru, adapun teknik analisis data yang digunakan adalah teknik analisis data kualitatif yaitu berupa data reduction (reduksi data), data display(penyajian data), conclusion drawing/verification (penarikan kesimpulan). Teknis analisis data dapat dilihat pada gambar 1.

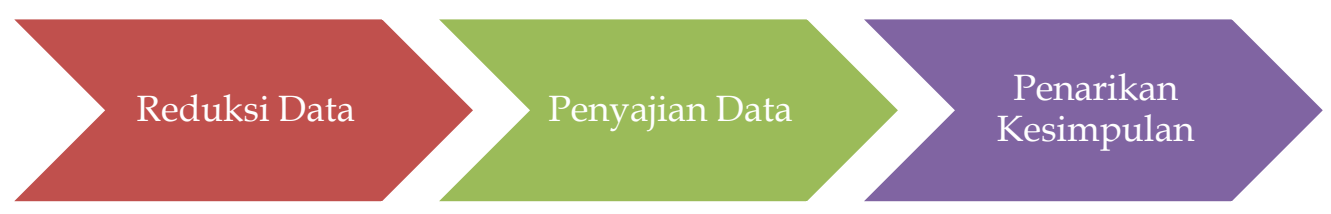

Gambar 1. Teknik analisis data

\section{HASIL DAN PEMBAHASAN}

Kemampuan guru yang berhubungan dengan pengaturan orang (kondisi Emosional)

Aspek yang akan dibahas berdasarkan kemampuan ini 1) pengaturan yang berhubungan dengan tingkah laku, 2) kedisiplinan, 3) perhatian, 4) minat belajar, dan 5) dinamika kelompok. Untuk hasil temuan dari wawancara yang telah di dapat sebagai berikut. 


\section{Aspek mentertibkan tingkah laku anak yang sering bermain dan berjalan ketika belajar}

Berdasarkan hasil temuan dari wawancara yang peneliti lakukan terhadap kemampuan guru yang berhubungan dengan pengaturan orang (kondisi emosional) aspek pengaturan atau menertibkan tingkah laku anak yang sering bermain dan berjalan ketika belajar, diketahui bahwa informan $1\left(\mathrm{I}_{1}\right)$ menertibkannya dengan memberikan permainan yang menarik kepada anak-anak, seperti tebak-tebakan, bernyanyi bersama, bercerita, kuis, dll. Dengan cara ini intensitas yang sering bermain dan berjalan ketika belajar sangat berkurang. Informan $2\left(\mathrm{I}_{2}\right)$ melakukannya dengan cara memberikan pujian dan hadiah kepada anak yang tenang. Secara tidak langsung anak yang sering bermain dan berjalan ketika belajar juga akan tenang karena ingin mendapatkan hadiah. Kemudian informan $3\left(\mathrm{I}_{3}\right)$ menertibkannya dengan cara memberikan hukuman yang mendidik bukan hukuman secara fisik. Misalnya minta mereka menghafal pelajaran sambil berdiri di depan kelas atau minta mereka menulis sesuatu yang berhubungan dengan pelajaran di depan kelas.

Hasil temuan dari wawancara tersebut menjelaskan kepada kita bahwa setiap guru harus mampu mengendalikan suasana belajar yang menyenangkan serta jauh dari keributan dan kesibukan yang dilakukan anak. Hal ini sejalan dengan temuan peneliti dalam sebuah jurnal bahwa tujuan guru dalam kelas adalah menciptakan lingkungan kelas yang positif. Perilaku yang ditargetkan untuk dimodifikasi adalah perilaku yang menganggu seluruh kelas yang meliputi perilaku berbicara di luar gilirannya, membuat kebisingan yang tidak perlu, bermain, dan berjalan ketika belajar (Wicaksono, 2013).

\section{Aspek Mendisiplinkan Anak untuk Selalu Mencuci Tangan}

Hasil temuan dari wawancara yang peneliti lakukan terhadap kemampuan guru yang berhubungan dengan pengaturan orang (kondisi emosional) aspek mendisiplinkan anak untuk selalu mencuci tangan, diketahui bahwa informan 1 (I1) mengatakan pertama-pertama menjelaskan kepada anak manfaat disiplin mencuci tangan untuk kesehatan, kemudian mencontohkan kepada anak cara mencuci tangan, dan menjadikan cuci tangan sebagai rutinitas sehari-hari. Waktunya menjelaskannya setiap mau masuk kelas, setiap mau makan dan setelah makan, dan setelah jam pulang. Informan 2 (I2) mengatakan dengan cara memberikan informasi kepada anak tentang manfaat mencuci tangan bagi kesehatan kita. Apabila anak mengetahui manfaat mencuci tangan, maka akan sendirinya anak akan disiplin untuk mencuci tangan. Sedangkan informan 3 (I3) dengan cara mengajarkan anak teknik mencuci tangan melalui gambar yang ditempel. Kami menempelkan gambar teknik mencuci tangan yang benar, mulai dari mambasuh tangan, mengosok, hingga mengeringkannya. Biasanya melalui gambar anak lebih mudah memahaminya.

Berdasarkan hasil temuan dari wawancara terhadap 3 informan di atas, dapat disimpulkan bahwa cara yang lakukan informan dalam mendisiplinkan anak untuk selalu mencuci tangan adalah: 1) menjelaskan kepada anak manfaat disiplin mencuci tangan untuk kesehatan, kemudian mencontohkan kepada anak cara mencuci tangan, dan menjadikan cuci tangan sebagai rutinitas sehari-hari, dan 2) mengajarkan anak teknik mencuci tangan melalui gambar yang ditempel.

Hasil wawancara tersebut menjelaskan kepada kita bahwa setiap guru maupun kepala sekolah berkewajiban mendisiplinkan anak untuk selalu mencuci tangan. Selain untuk melindungi dirinya sendiri maupun untuk melindungi temannya atau orang lain. Berdasarkan hasil temuan peneliti dalam sebuah jurnal bahwa langkah kongkrit dari usaha ini adalah berupa penyuluhan atau pemberian informasi pengetahuan (transfer of knowledge), pembiasaan yang baik (good habit) sejak dini disertai pendampingan atau praktik langsung dengan video pembelajaran. Langkah ini adalah sebuah keniscayaan guna menghadang agar covid-19 tak makin meluas (Suprapto et al., 2020).

Selanjutnya dalam keputusan 4 Menteri bahwa setiap satuan pendidikan harus memastikan kecukupan cairan disinfektan, sabun cuci tangan, air bersih di setiap fasilitas CTPS, dan cairan pembersih tangan (hand sanitizer) (Keputusan Bersama 4 Menteri, 2021). 
Tujuan yang ingin dicapai dari mendisiplinkan anak untuk selalu cuci tangan yang baik dan benar ini adalah agar anak-anak dapat memahami tata cara, dan dapat mempraktikkan bagaimana cuci tangan yang baik dan benar. Diharapkan setelah pelaksanaan kegiatan mencuci tangan tersebut dibiasakan, anak-anak menjadi lebih gemar mencuci tangan sesering mungkin dengan baik dan benar.

\section{Aspek Menunjukkan Media Untuk Menarik Minat atau Perhatian anak}

Hasil temuan dari wawancara yang peneliti lakukan terhadap kemampuan guru yang berhubungan dengan pengaturan orang (kondisi emosional) aspek menunjukkan media untuk menarik minat atau perhatian anak, diketahui bahwa informan 1 (I1) mengatakan selalu menunjukkan media, karena media dapat meningkatkan dan mengarahkan perhatian anak sehingga dapat menimbulkan minat dan motivasi belajar anak. Dengan menunjukkan media memudahkan siswa berinterkasi secara langsung dalam proses pembelajaran. Sedangkan informan 2 (I2) juga menjelaskan benar selalu menunjukkan media, dengan menunjukkan media selain menarik minat atau perhatian anak, bahan pembelajaran akan lebih jelas maknanya sehingga dapat lebih dipahami oleh anak dan memungkinkannya menguasai dan mencapai tujuan pembelajaran. Kemudian Informan 3 (I3) menjelaskan bahwa tidak selalu menunjukkan media, tapi hampir sering. Karena media memperjelas penyajian pelajaran agar tidak terlalu bersifat verbalistis (dalam bentuk kata-kata tertulis atau lisan belaka).

Berdasarkan hasil temuan dari wawancara terhadap 3 informan di atas, dapat disimpulkan bahwa informan mengatakan selalu dan hampir sering menunjukkan media untuk menarik minat atau perhatian anak, dengan alasan media dapat meningkatkan dan mengarahkan perhatian anak sehingga dapat menimbulkan minat dan motivasi belajar anak, bahan pembelajaran akan lebih jelas maknanya, dan media memperjelas penyajian pelajaran agar tidak terlalu bersifat verbalistis (dalam bentuk kata-kata tertulis atau lisan belaka).

Hal tersebut didukung oleh (Nurseto, 2012) bahwa media sangat bermanfaat dalam proses belajar mengajar: (1) dapat menumbuhkan motivasi belajar siswa karena pengajaran akan lebih menarik perhatian mereka; (2) makna bahan pengajaran akan menjadi lebih jelas sehingga dapat dipahami siswa dan memungkinkan terjadinya penguasaan serta pencapaian tujuan pengajaran; (3) metode mengajar akan lebih bervariasi, tidak semata-mata didasarkan atas komunikasi verbal melalui kata-kata; dan (4) siswa lebih banyak melakukan aktivitas selama kegiatan belajar, tidak hanya mendengarkan tetapi juga mengamati, mendemonstrasikan, melakukan langsung, dan memerankan.

Sedangkan Hanafiah dan Suhana (2009:59) menyatakan bahwa media pembelajaran merupakan segala bentuk perangsang dan alat yang disediakan guru untuk mendorong siswa belajar secara cepat, tepat, mudah, benar dan tidak terjadinya verbalisme. Selain itu, media pembelajaran dirancang untuk alat bantu pendengaran dan penglihatan (audio visual aid) bagi peserta didik dalam rangka memperoleh pengalaman belajar secara signifikan.

\section{Aspek Mengembalikan Minat Belajar Anak}

Hasil temuan dari wawancara yang peneliti lakukan terhadap kemampuan guru yang berhubungan dengan pengaturan orang (kondisi emosional) aspek mengembalikan gairah belajar anak, informan 1 mengatakan bahwa dengan cara membuat tampilan baru pada kelas dengan mengatur ulang meja hingga menghias beberapa sudut kelas. Suasana yang menyenangkan dapat menjadi bekal awal mengembalikan gairah belajar anak. Informan 2 (I2) mengatakan dengan cara memulai pelajaran dengan konten yang menyenangkan, sehingga dapat membantu siswa kembali berminat untuk belajar, dan siswa juga tidak kaget dan stres dalam belajar. Sedangkan informan 3 (I3) mengatakan dengan cara memberikan hadiah atau penghargaan, karena terkadang tidak semua anak bisa kembali berminat belajar jika hanya diberikan pujian saja. Selain itu, saya mencoba menciptakan mindset anak bahwa sekolah adalah sesuatu yang menyenangkan. 
Berdasarkan hasil temuan dari wawancara terhadap 3 informan di atas, dapat disimpulkan bahwa berbagai cara yang dilakukan guru untuk mengembalikan minat belajar anak, diantaranya: 1) membuat tampilan baru pada kelas dengan mengatur ulang meja hingga menghias beberapa sudut kelas, 2) memulai pelajaran dengan konten yang menyenangkan, dan 3) memberikan hadiah atau penghargaan. Hasil wawancara tersebut menjelaskan kepada kita bahwa betapa pentingnya mengembalikan minat belajar anak, karena jika anak sudah tidak berminat untuk mengikuti pelajaran, bagaimana mungkin anak akan mudah menerima materi yang disampaikan guru.

Berdasarkan hasil temuan peneliti dalam sebuah jurnal bahwa strategi yang tepat untuk mengembalikan minat belajar anak di masa pandemi Covid-19 ini adalah dengan cara komunikasi persuasif, menggunakan media yang tepat, buatlah pembelajaran menjadi menarik, jangan terlalu banyak membebani peserta didik dengan terlalu banyak informasi (Eis Imroatul Muawanah, 2021). Sedangkan Darmadi (2012) menjelaskan bahwa tujuan mengelola kelas adalah agar semua siswa yang ada di dalam kelas dapat belajar dengan optimal dan mengatur sarana pembelajaran serta mengendalikan suasana belajar yang menyenangkan untuk mencapai tujuan belajar

\section{SIMPULAN}

Guru-guru TK Bunga Teratai Kecamatan Tapung Kabupaten Kampar telah memperlihatkan kemampuan dalam mengelola kelas berdasarkan prokes covid, meskipun masih ada yang perlu perbaikan. Guru dapat mengendalikan suasana belajar dengan baik, mendisiplinkan anak untuk mencuci tangan serta selalu memberikan pembelajaran dengan media yang dapat menarik minat dan perhatian anak, membuat tampilan baru pada kelas dengan mengatur ulang meja hingga menghias beberapa sudut kelas, memulai pelajaran dengan konten yang menyenangkan, dan memberikan hadiah atau penghargaan.

\section{UCAPAN TERIMA KASIH}

Terimakasih kepada pembimbing yang sudah membantu memberikan masukan pada penelitian ini. Terimakasih kepada guru-guru TK Teratai Kec. Tapung yang sudah bersedia menjadi informan.

\section{DAFTAR PUSTAKA}

Adhyati. (2016). Kemampuan Guru dalam Mengelola Kelas untuk Siswa yang Berkebutuhan Khusus di SDN 16 Banda Aceh. Jurnal Ilmiah Pendidikan Guru Sekolah Dasar FKIP Unsyiah, 1(2), 1-10.

Anugrahana, A. (2020). Hambatan, Solusi dan Harapan: Pembelajaran Daring Selama Masa Pandemi Covid-19 Oleh Guru Sekolah Dasar. Scholaria: Jurnal Pendidikan Dan Kebudayaan, 10(3), 282-289. https://doi.org/10.24246/j.js.2020.v10.i3.p282-289

Arikunto, S. (2011). Prosedur Penilian Suatu Pendekatan Praktik. Jakarta: Rineka Cipta.

Ayu Wulandari, G. N. S. A. (2020). Dramatik Pembelajaran Daring pada Masa Pandemi Covid19 (Studi Pada Persepsi Mahasiswa PGSD Undiksha). Mimbar PGSD Undiksha, 8(3), 515-526.

Darmadi, H. (2012). Kemampuan Dasar Mengajar. Bandung: Alfabeta.

Eis Imroatul Muawanah, A. M. (2021). Strategi Meningkatkan Motivasi Belajar Siswa Selama Pandemi Covid - 19: Literature Review. Jurnal Ilmiah Bimbingan Konseling Undiksha, XII(1), 90-98. https://doi.org/10.23887/jibk.v12i1.31311

Hamalik, O. (2013). Proses Belajar Mengajar. Jakarta: Bumi Aksara.

Herliandry, L. D., Nurhasanah, N., Suban, M. E., \& Kuswanto, H. (2020). Pembelajaran Pada Masa Pandemi Covid-19. JTP - Jurnal Teknologi Pendidikan, 22(1), 65-70. https://doi.org/10.21009/jtp.v22i1.15286 
Hilna Putria, Luthfi Hamdani Maula, D. A. U. (2020). Analisis Proses Pembelajaran Dalam Jaringan (DARING) Masa Pandemi COVID-19 pada Guru Sekolah Dasar. Jurnal Basicedu, 4(4), 861-872. https://doi.org/10.31004/basicedu.v4i4.460

Kadir, F. (2014). Keterampilan Mengelola Kelas dan Implementasinya dalam Proses Pembelajaran. Jurnal Al-Ta'dib, 7(2), 16-36.

Keputusan Bersama 4 Menteri. (2021). Panduan Penyelenggaraan Pembelajaran Pada Tahun Ajaran 2020/2021 dan Tahun Akademik 2020/2021 di Masa Pandemi Covid -19). Jakarta: Kemendikbud.

Nurseto, T. (2012). Membuat Media Pembelajaran yang Menarik. Jurnal Ekonomi Dan Pendidikan, 8(1), 19-35. https:// doi.org/10.21831/jep.v8i1.706

Oktafia Ika Handarini \& Siti Sri Wulandari. (2020). Pembelajaran Daring Sebagai Upaya Study From Home (SFH) Selama Pandemi Covid 19. Jurnal Pendidikan Administrasi Perkantoran (JPAP), 8(3), 496-503. Retrieved from https://journal.unesa.ac.id/index.php/jpap/article/view/8503

Santiyadnya, N. (2017). Keterampilan Guru dalam Mengelola Kelas pada Pembelajaran Prakarya dan Kewirausahaan di SMA Negeri 1 Singaraja. Jurnal Pendidikan Teknologi Dan Kejuruan, 14(2). https:/ / doi.org/10.23887/jptk-undiksha.v14i2.11106

Suprapto, R., Hayati, M., Nurbaity, S., Anggraeni, F., Haritsatama, S., Sadida, T. Q., ... Pratama, F. A. (2020). Pembiasaan Cuci Tangan yang Baik dan Benar pada Siswa Taman Kanak-Kanak (TK) di Semarang. Jurnal Surya Masyarakat, 2(2), 139. https:// doi.org/10.26714/jsm.2.2.2020.139-145

Suwardi. (2019). Pengaruh Kemampuan Guru dalam Mengelola Kelas Terhadap Pembelajaran Efektif di Taman Kanak-Kanak. Jurnal Audhi, 2(1), 37-48. https:// doi.org/10.36722/jaudhi.v2i1.579

Utama, G. . (2016). Kemampuan Guru Mengelola Kelas 4 dan 5 SD Negeri Pandeyen, Umbulharjo, Yogyakarta. Jurnal Pendidikan Guru Sekolah, 16(5), 1.536-1.543.

Wicaksono, T. (2013). Perilaku Menganggu di Kelas. Jurnal Paradigma, 15(8), 115-130. 